\title{
Size-resolved cloud condensation nuclei concentration measurements in the Arctic: two case studies from the summer of 2008
}

\author{
J. Zábori ${ }^{1}$, N. Rastak ${ }^{1}$, Y. J. Yoon ${ }^{2}$, I. Riipinen ${ }^{1}$, and J. Ström ${ }^{1}$ \\ ${ }^{1}$ Department of Environmental Science and Analytical Chemistry, Stockholm University, 10691 Stockholm, Sweden \\ ${ }^{2}$ Korea Polar Research Institute, Incheon 406-840, Republic of Korea
}

Correspondence to: J. Zábori (julia.zabori@aces.su.se)

Received: 5 December 2014 - Published in Atmos. Chem. Phys. Discuss.: 23 February 2015

Revised: 27 October 2015 - Accepted: 25 November 2015 - Published: 15 December 2015

\begin{abstract}
The Arctic is one of the most vulnerable regions affected by climate change. Extensive measurement data are needed to understand the atmospheric processes governing this vulnerability. Among these, data describing cloud formation potential are of particular interest, since the indirect effect of aerosols on the climate system is still poorly understood. In this paper we present, for the first time, sizeresolved cloud condensation nuclei $(\mathrm{CCN})$ data obtained in the Arctic. The measurements were conducted during two periods in the summer of 2008: one in June and one in August, at the Zeppelin research station $\left(78^{\circ} 54^{\prime} \mathrm{N}, 11^{\circ} 53^{\prime} \mathrm{E}\right)$ in Svalbard. Trajectory analysis indicates that during the measurement period in June 2008, air masses predominantly originated from the Arctic, whereas the measurements from August 2008 were influenced by mid-latitude air masses. CCN supersaturation (SS) spectra obtained on the 27 June, before size-resolved measurements were begun, and spectra from the 21 and 24 August, conducted before and after the measurement period, revealed similarities between the 2 months. From the ratio between $\mathrm{CCN}$ concentration and the total particle number concentration $(\mathrm{CN})$ as a function of dry particle diameter $\left(D_{\mathrm{p}}\right)$ at a SS of $0.4 \%$, the activation diameter $\left(D_{50}\right)$, corresponding to $\mathrm{CCN} / \mathrm{CN}=0.50$, was estimated. $D_{50}$ was found to be 60 and $67 \mathrm{~nm}$ for the examined periods in June and August 2008, respectively. Corresponding $D_{50}$ hygroscopicity parameter $(\kappa)$ values were estimated to be 0.4 and 0.3 for June and August 2008, respectively. These values can be compared to hygroscopicity values estimated from bulk chemical composition, where $\kappa$ was calculated to be 0.5 for both June and August 2008. While the agreement between the 2 months is reasonable, the difference
\end{abstract}

in $\kappa$ between the different methods indicates a size dependence in the particle composition, which is likely explained by a higher fraction of inorganics in the bulk aerosol samples.

\section{Introduction}

The Arctic represents a region of special interest for atmospheric research because it is (i) very sensitive to changes in radiative forcing owing to a direct feedback mechanism, (ii) expecting greater anthropogenic activity from increased shipping and natural resource explorations in the near future and (iii) still poorly understood in terms of climate controlling processes, largely due to the lack of observational data. One of the most significant uncertainties in climate prediction is the role of clouds, and in particular, the influence of anthropogenic activities on clouds. In general, clouds have the ability to both cool the surface by reflecting incoming solar radiation back to space, or warm the surface by reemitting long-wave radiation back to the surface (Boucher et al., 2013). The formation of clouds is dependent on the presence of excess water vapour in the air and on the presence of aerosol particles having cloud condensation nuclei (CCN) properties. Such particles must have sufficient size and hygroscopicity to act as sites for cloud droplet formation. In this study, two short case studies are presented, based on observations conducted in June and August 2008 at the Zeppelin station, Svalbard. These data complement the existing $\mathrm{CCN}$ and aerosol measurements conducted in the Arctic, but for the first time the $\mathrm{CCN}$ properties here are deter- 
mined online as a function of dry particle size. R. H. Moore et al. (2011) have provided a brief literature review of CCN measurements in the Arctic; however, to set our study in the context of other studies and to summarize the available information concerning Arctic CCN, we also present a short literature overview, including some of the most recent studies. For clarity, data are first grouped into land-based measurements, then measurements from ships and followed by aircraft measurements.

\subsection{Ground-based measurements}

Shaw (1986) examined the CCN spectra of air masses characterized by Arctic haze during January and February 1985 in central Alaska. The maximum supersaturation (SS) was found to be around $0.33 \%$, and the dominant $\mathrm{CCN}$ consisted of soluble particles at a concentration of a few hundred per $\mathrm{cm}^{-3}$, characterized by a rather large size of approximately $1 \mu \mathrm{m}$.

Silvergren et al. (2014) presented chemical and physical properties of aerosols collected at the Zeppelin research station, Svalbard from September 2007 to August 2008. Hygroscopic growth and cloud-forming potential were examined on a monthly basis. From this, it was shown that during the summer months, the SS has the greatest impact on the number of CCN. As the aerosol sulphate and nitrate mass concentrations reached a maximum between March and May, it was concluded that these months presented the most unfavourable cloud-forming properties of the entire year. From September to February, sea salt was present in the highest mass concentrations. Both the growth factor and the values of the hygroscopicity parameter $\kappa$ ranging approx. between 0.7 and 1 were determined to be highest in October, which was noted as the month with the most favourable cloud-forming potential.

\subsection{Ship-based measurements}

Bigg and Leck (2001) reported the results from CCN measurements conducted on an icebreaker at latitudes higher than $80^{\circ} \mathrm{N}$, from 15 July to 23 September 1996 . They observed $\mathrm{CCN}$ concentrations between 1 and $1000 \mathrm{~cm}^{-3}$ at a SS of $0.25 \%$ over the measurement period. Daily median CCN concentrations at the same SS were around $15-50 \mathrm{~cm}^{-3}$, and over the course of a day, concentrations could vary by up to 1 order of magnitude. A decrease in $\mathrm{CCN}$ concentration of approximately 1 order of magnitude was observed when air was being transported from the open ocean to the pack ice. The authors suggested that this occurred as a result of wet scavenging. However, after this $36 \mathrm{~h}$ period, an increase in $\mathrm{CCN}$ concentration was observed, which was thought to be related to local aerosol production from bubble bursting occurring between the pack ice.

The results of CCN measurements conducted during 3 weeks in August and September 2008 on board the ice- breaker "Oden", which was drifting passively to the north of $87^{\circ} \mathrm{N}$, are presented by Martin et al. (2011). A mean SS of $0.10 \%$ resulted in a mean CCN concentration of $14 \pm 11 \mathrm{~cm}^{-3}$, which increased up to $47 \pm 37 \mathrm{~cm}^{-3}$ for a mean SS of $0.73 \%$. In general, CCN closure within the measurement uncertainties was successful for SSs of 0.10 , 0.15 and $0.20 \%$, assuming an internally mixed aerosol with a nearly insoluble organic volume fraction. However, the calculated CCN concentrations for SSs of 0.41 and $0.73 \%$ overestimated the measured CCN concentrations; this is suggested to be a result of differing chemical properties of different aerosol sizes.

\subsection{Aircraft measurements}

Hoppel et al. (1973) present results of aircraft measurements from February 1972 above Alaska, approximately $160 \mathrm{~km}$ north of Fairbanks. A strong temperature inversion was observed during the measurements, and an increase in CCN concentration, approximately from 100 to $400 \mathrm{~cm}^{-3}$, was recorded to accompany an altitude increase, from 1.75 to $4 \mathrm{~km}$. Moreover, the increase of CCN concentration with an increase in SS was dependent on the altitude of the measurements. At $4.3 \mathrm{~km}$ altitude, the $\mathrm{CCN}$ concentration increased approximately from $50 \mathrm{~cm}^{-3}$ at $0.3 \% \mathrm{SS}$ to $600 \mathrm{~cm}^{-3}$ at $1 \%$ SS. In contrast, at approximately $0.3 \mathrm{~km}$ above sea level, an increase of $\mathrm{CCN}$ concentration was observed approximately from $60 \mathrm{~cm}^{-3}$ at $0.3 \% \mathrm{SS}$ to $100 \mathrm{~cm}^{-3}$ at $0.8 \% \mathrm{SS}$, but no further increase was seen up to a SS of $1 \%$. Hoppel et al. (1973) suggested that these data may indicate the production of $\mathrm{CCN}$ in the upper troposphere or in the stratosphere, followed by downward mixing into the lower atmospheric layers.

CCN data from aircraft measurements conducted during April 1992 over the Arctic Ocean were presented by Hegg et al. (1995). Measurements took place around $350 \mathrm{~km}$ from the Alaskan coast between 0.03 and $4 \mathrm{~km}$ altitude; they show CCN concentration to vary between 19.9 and $92.7 \mathrm{~cm}^{-3}$, with a mean value of $47 \pm 19 \mathrm{~cm}^{-3}$ measured at $1 \% \mathrm{SS}$. Hegg et al. (1995) also observed an increase in CCN concentration with altitude up to $3 \mathrm{~km}$, but note that the data points above $3 \mathrm{~km}$ altitude are too sparse to reliably predict any trend. Below $1.6 \mathrm{~km}$ altitude the fraction of particles that act as CCN ranged between 0.002 and 0.38 with an average of $0.15 \pm 0.08$ at $1 \% \mathrm{SS}$. No reliable $\mathrm{CN}$ data were obtained for altitudes higher than $1.6 \mathrm{~km}$ due to a frozen valve. Hegg et al. (1995) concluded that their data are an indication of particle production at higher altitudes compared to lower altitudes.

Results of aircraft measurements made during 11 flights over Alaska in June 1995 were published by Hegg et al. (1996) and compared to measurements presented in Hegg et al. (1995). This further study concluded that the fraction of activated particles is, on average, approximately 0.10 at a SS of $1 \%$. They therefore suggested that the number of 
smaller particles is higher during June 1995 than in the spring of 1992.

Yum and Hudson (2001) presented vertical CCN profiles obtained at least $500 \mathrm{~km}$ north of the Alaskan coast during a flight campaign in May 1998. They observed a clear increase in $\mathrm{CCN}$ concentration with an increase in altitude when low stratus clouds were present. However, under noncloudy conditions, an increase in CCN concentration was only observed at heights with an air pressure lower than 700 mbar. Average CCN concentrations measured at a SS of $0.8 \%$ were $257 \pm 79$ and $76 \pm 29 \mathrm{~cm}^{-3}$ above and below the stratus cloud, respectively. In contrast, the average CCN concentrations obtained at lower altitudes (comparable to the measurements beneath the clouds) during non-cloudy flights was $250 \pm 41 \mathrm{~cm}^{-3}$. The authors proposed that the CCN concentrations in the low cloudy boundary layer are controlled by cloud scavenging, resulting in a clearly altitude-dependent $\mathrm{CCN}$ density profile. Analyses of CCN spectra were also conducted, using the formula $N=C \times \mathrm{SS}^{k}$, where $N$ is the $\mathrm{CCN}$ concentration at a given $\mathrm{SS}, C$ is the $\mathrm{CCN}$ concentration at $1 \% \mathrm{SS}$ and $k$ describes the slope of the function. The $\mathrm{CCN}$ spectra at specific height levels showed larger $k$ values under the non-cloudy conditions, compared to when clouds were present (for example, 2.214 compared with 1.474 at $0.04-0.1 \% \mathrm{SS}$ and at $560-660 \mathrm{hPa}$ ), with the exception of the highest SS values found at lower altitudes.

R. H. Moore et al. (2011) presented results from five research flights over the Alaskan Arctic during April 2008, beginning from Fairbanks and covering parts of the Beaufort Sea. The air masses sampled variously represented background conditions, biomass burning plumes, anthropogenic pollution and Arctic boundary layer conditions. Calculated activation curves with $\mathrm{SS}$ values ranging between 0.1 and $0.6 \%$ showed that at least $70 \%$ of the particles were activated for SS at around $0.2 \%$ for all air masses. It was therefore concluded that this similarity in observed activation pattern, despite the differences in chemical composition, is a result of aerosol size, which largely determines CCN activity. However, the authors pointed out that for SS between 0.3 and $0.6 \%$ it is likely that the particle chemical composition controls the maximum fraction of particles that can act as CCN.

Lathem et al. (2013) presented results of CCN measurements conducted during research flights from 26 June to 14 July 2008. The flight campaigns set-off from Cold Lake, Alberta, Canada and passed through the northeastern Canadian Arctic before heading to the west coast of Greenland. During the flights, the various air masses were characterized by biomass burning, boreal forest background, Arctic background and anthropogenic industrial pollution. Median $\mathrm{CCN}$ concentrations were highest for air masses influenced by fresh biomass burning, at $7778 \mathrm{~cm}^{-3}$ at standard temperature and pressure (STP, $1013 \mathrm{hPa}$ and $273.15 \mathrm{~K})$. At a SS of $0.55 \%$ the $\mathrm{CCN} / \mathrm{CN}$ ratio was around 0.89 for those particles resulting from fresh biomass burning. The lowest $\mathrm{CCN} / \mathrm{CN}$ activation ratio was 0.15 at $\mathrm{SS} 0.55 \%$, observed for air masses characterized by industrial pollution, with a $\mathrm{CCN}$ concentration of $341 \mathrm{~cm}^{-3}$. The Arctic background air mass resulted in a moderate activation ratio of 0.52 for $0.5 \%$ $\mathrm{SS}$, while CCN concentration was $247 \mathrm{~cm}^{-3}$.

During a flight campaign over the northern slopes of Alaska in April 2008, Hiranuma et al. (2013) collected ambient particles, dry residuals of mixed-phase cloud droplets and ice crystals. They analysed their size and chemical structure using an electron microscope in combination with various X-ray techniques. Note that the results should be interpreted with caution due to the limited number of samples. However, the limited data showed that the residuals of cloud droplets were enriched with respect to carbonate and black carbon, compared to the ambient particles. Significant mixing was also observed in the cloud droplet residuals. Additionally, during a period of high ice nucleation efficiency, residuals were enriched in sodium and magnesium salts compared to the ambient particles.

The studies described above reveal the significant variability in $\mathrm{CCN}$ concentration across the Arctic, likely resulting from differing locations of CCN production (upper troposphere vs. lower boundary layer), production mechanisms, in-cloud processing and the origins of air masses. Several studies indicate an increase in $\mathrm{CCN}$ with increasing altitude in the lower half of the troposphere. However, the controlling mechanism for this increase is still unclear. In this study, we compare bulk CCN properties with those found in previous studies, and we also explore the size dependence of $\mathrm{CCN}$ activation potential for the Arctic aerosols by combining a DMPS (Differential Mobility Particle Sizer) system with a $\mathrm{CCN}$ counter (CCNC). Although size-dependent CCN activation has been studied worldwide (Bhattu and Tripathi, 2014; Rose et al., 2010; Paramonov et al., 2013; Gunthe et al., 2009), according to our knowledge, this is the first study presenting size-resolved CCN activation in the Arctic.

\section{Methods}

\subsection{Location}

Measurements were made at the Zeppelin research station $\left(78^{\circ} 54^{\prime} \mathrm{N}, 11^{\circ} 53^{\prime} \mathrm{E}, 474 \mathrm{~m}\right.$ above sea level), which is situated approximately $2 \mathrm{~km}$ south-west of the small settlement $\mathrm{Ny}$ Allesund, in Svalbard. The station is seldom affected by local pollution and therefore can be considered to represent remote Arctic atmospheric conditions. Continuous aerosol measurements were begun in the year 2000, concerning which detailed information can be found in Tunved et al. (2013).

\subsection{Instrumentation and experimental setup}

Particle number size distributions were measured using a closed-loop Differential Mobility Particle Sizer (DMPS), consisting of a medium-sized Hauke Differential Mobility Analyzer (DMA) in combination with a TSI Condensation 
Particle Counter (CPC) 3010. Measurements were performed within 40 different size bins, with particle diameters ranging between 10 and $900 \mathrm{~nm}$. Each particle size range was measured for $10 \mathrm{~s}$, followed by a lag time of $5 \mathrm{~s}$ before the next size range was measured. Simultaneously, total particle number concentrations were precisely measured using a TSI CPC 3025 with a lower cut-off size of $3 \mathrm{~nm}$, and by a TSI CPC 3010 with a lower cut-off size of $10 \mathrm{~nm}$. A commercially available DMT CCN counter connected to a $1 / 4^{\prime \prime}$ stainless steel tubing inlet registered $\mathrm{CCN}$ concentrations at SSs of $0.2,0.4,0.6,0.8$ or $1 \%$. In the CCNC scanning mode, each SS level was measured for approximately $5 \mathrm{~min}$ before changing to the next SS level. After completing the 1\% SS level, the measurements began again at $0.2 \% \mathrm{SS}$ after at least a 3 min break in the measurements. The shared inlet of the DMPS, TSI CPC 3025 and TSI CPC 3010 was precipitation protected with an estimated cut-off size of $5 \mu \mathrm{m}$.

In the standard configuration, these two instrument systems operate independently. In this study, however, we combined the two systems such that the DMA first selects a nearly mono-disperse aerosol, which is then supplied to the CCNC. For the CCN size-resolved concentration measurements, the CCNC was connected to the DMA and SS was fixed at $0.4 \%$. The number of size bins of the DMPS system was also reduced from 40 to 15 , and the time each particle size was measured was extended from 10 to $35 \mathrm{~s}$ to improve counting statistics. The lower and upper bounds of the DMPS scans were also narrowed to 15 and $400 \mathrm{~nm}$, respectively. The two different setups of the CCNC are shown in Fig. 1.

\subsection{Experiments}

Two case studies are presented here, consisting of CCN sizeresolved number concentration measurements conducted during summer 2008. The measurement period for the first case study lasted from around 09:40 UTC on 27 June to around $10: 15$ on 29 June during which about 290 sizeresolved CCN scans were conducted. The minimum and maximum temperatures for this period were 3.8 and $9.4^{\circ} \mathrm{C}$, respectively. The measurement period for the second case study began at around 07:30 on 21 August and ended at around 10:50 on 24 August, resulting in about 374 sizeresolved CCN scans. The minimum and maximum temperatures for this period were 2.8 and $5.9^{\circ} \mathrm{C}$, respectively. Before the size-resolved $\mathrm{CCN}$ concentration measurements were performed in June, CCN spectra were obtained from the total aerosols over a period of approximately $5 \mathrm{~h}$. Unfortunately, no spectra were measured directly after the first $\mathrm{CCN}$ sizeresolved experiment ended on 29 June. However, during the study in August, CCN spectra were determined for approximately $17 \mathrm{~h}$ on 21 August, before the CCN size-resolved experiment began, and for approximately $13 \mathrm{~h}$ on 24 August after the experiment ended. In addition, 5-day backward trajectories were calculated on an hourly basis, using the online web version of the NOAA HYSPLIT Model (Draxler and

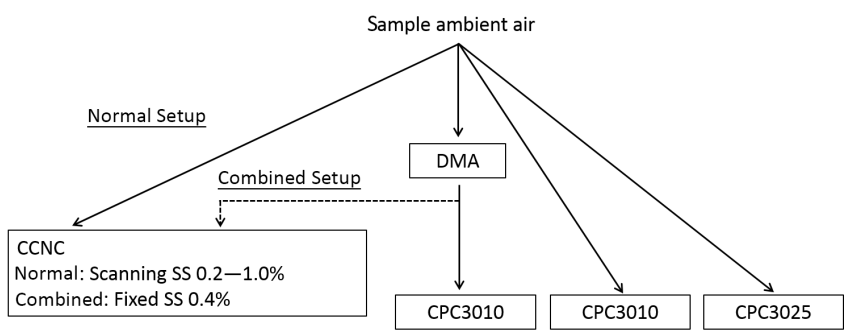

Figure 1. Scheme of the two different measurement modes for the cloud condensation nuclei counter (CCNC). When CCN sizeresolved number concentration measurements took place, the CCNC was connected behind the Differential Mobility Analyzer and the supersaturation was set to $0.4 \%$. During normal operation, the CCNC was connected parallel to the DMA and SS alternated between 0.2 and $1.0 \%$.

Rolph, 2015; Rolph, 2015), to analyse the origins of the air masses from which the observed results presented in the next section were derived.

\section{Results and discussion}

\subsection{Time series analysis}

Particle number size distributions observed from 27 to 30 June 2008 are presented in Fig. 2a. The vertical purple lines in this figure indicate the beginning and the end point of the measurement period for the size-resolved CCN number concentration data. Based on the particle number size distribution, at least three characteristic periods can be distinguished: (i) from midnight to approximately midday of 27 June, when particles with diameters of approximately $70 \mathrm{~nm}$ dominate the particle concentration; (ii) from midnight to approximately midday of 28 June, when particle number concentrations are highest for particle diameters of approximately $20 \mathrm{~nm}$ and (iii) from approximately midday on 29 June to the following midnight, when the concentration of particles with diameters approximately between 20 and $70 \mathrm{~nm}$ increased to more than $1000 \mathrm{~cm}^{-3}$ (cf. Fig. 2a). For the period 27 to 29 June, 5-day backward trajectories were calculated for each hour (shown above Fig.2a and below Fig 2b). Air masses arriving between 00:00 and 11:00 at the Zeppelin station are characterized by both air coming from a southerly direction and air with its residence time exclusively at the high Arctic. From 12:00 on 27 June until midnight of 29 June air masses reaching the Zeppelin station have a clear central Arctic origin. In addition to the trajectory analyses, Lidar measurements from Ny-Ålesund, part of the Micro Pulse Lidar Network (http://mplnet.gsfc.nasa.gov/, last access: 28 November 2013) were investigated for the presence of clouds or precipitation in the vicinity of the Zeppelin station. All times mentioned in these data refer to coordinated universal time. Lidar measurements on 27 June 2008 

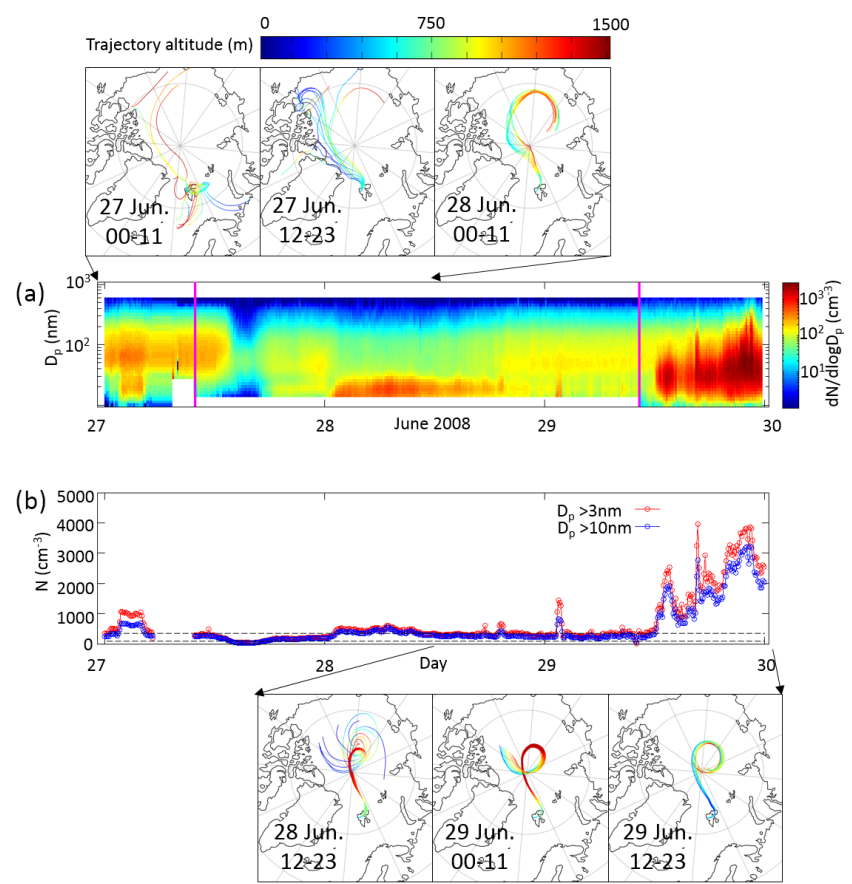

Figure 2. (a) Particle number size concentration measured before, during and after the size-resolved $\mathrm{CCN}$ concentration measurements were conducted in June 2008. Purple vertical lines indicate the start and end time of the CCN size-resolved concentration measurements. (b) Time series of the 8 min medians from CPC measurements for the same period in June 2008. Horizontal dashed lines represent the 25th and 75th percentile of the $\mathrm{CN}$ number concentration for June during the years 2001 to 2010. Trajectory plots show 5-day backward trajectories, calculated for every hour. Trajectory plots on top of panel (a) show air masses arriving between the 27 and midday of the 28 June at the Zeppelin research station. Trajectory plots below panel (b) show air masses arriving between midday of the 28 June to midnight of the 29 June at the Zeppelin research station.

in Ny-Ålesund showed only high clouds (altitude $>5 \mathrm{~km}$ ), from approximately 09:00. Before 09:00, cloud-free conditions predominated at the measurement site. High clouds and cloud-free conditions alternated during 28 and 29 June 2008; therefore, the Zeppelin station can be regarded as cloud-free during this time (cf. Fig. 3).

The time series of particle number size distribution (Fig. 2a) is accompanied by two time series of total aerosol number concentrations for particles having a lower cut-off size of 3 and $10 \mathrm{~nm}$, respectively (Fig. 2b). Although particles smaller than $10 \mathrm{~nm}$ are unlikely to be $\mathrm{CCN}$, the combination of the two CPC instruments permit detection of particles that are a result of recent new particle formation. The combination of 5-day backward trajectory analyses, lidar measurements, particle number size distributions and total aerosol concentration time series gives a rounded picture of the conditions that prevailed during the experimental period.
The entire period from 27 to 30 June 2008 is characterized by a maximum of particle concentrations occurring at particle diameters below $100 \mathrm{~nm}$. This is in line with the results of Tunved et al. (2013), who analysed long-term particle number size distributions at the Zeppelin station during the years 2000-2010. In their study, the authors concluded that the Arctic summer aerosol number size distribution (JuneAugust) is characterized by a dominance of particles with diameters less than the accumulation diameter. It is proposed that these aerosols are most likely formed within the Arctic itself. This explanation of local production agrees with our calculated trajectories (Fig. 2), which show transport almost only within the Arctic. In addition, the lidar data from the period from 27 to 30 June 2008 does not indicate any cloud processing of the aerosols in the lower atmosphere boundary layer at the measurement site.

From midnight to approximately midday of 27 June, particles with diameters of approximately $70 \mathrm{~nm}$ dominate the particle concentration. The associated trajectory plot (Fig. 2) indicates that this pattern may result from a mixture of air masses, originating from the Norwegian Sea as well as from the Arctic Ocean.

During the early morning hours of 28 June 2008 a sharp increase in total particle number concentration is observed (Fig. 2b). The highest concentration of particle numbers is found for particles with dry diameters of less than $20 \mathrm{~nm}$ (Fig. 2a), which points, alongside the sharp increase in particle number concentration, towards new particle formation during previous hours. The process of particle formation is not yet fully understood (Komppula et al., 2003; Yli-Juuti et al., 2011; Ortega et al., 2012), but sulphuric acid and organic compounds have been found to be the key components (Riipinen et al., 2007; Kuang et al., 2008; Sipilä et al., 2010; Kulmala et al., 2013). Most nucleation events take place during the daylight hours, which indicates the importance of photochemistry in the nucleation process. However, at some locations particle formation events are also observed at night when there is no ambient light (Ortega et al., 2012). In Ny-Ålesund, the polar day lasts from around 18 April to 23 August; therefore, the measurements made herein during June 2008 lie within this daylight period. Tunved et al. (2013) presented averaged diurnal particle number size distributions for June, based on observations made during 2000-2010, and found that the concentrations of particles with diameters less than $20 \mathrm{~nm}$ predominantly begin to increase at around noon. Presented data indicate that an increase of particle concentration occured later in the day. In the Arctic environment, it has been suggested that dimethyl sulphide plays an important role as a condensing vapour for the nucleation process (Chang et al., 2011). Tunved et al. (2013) stated that another requirement of particle nucleation in the Arctic is a low condensation sink, which means a low concentration of particles in the accumulation mode. These authors showed that the particle mass is strongly related to accumulated precipitation along the transport path (cf. Fig. 15 in Tunved et 


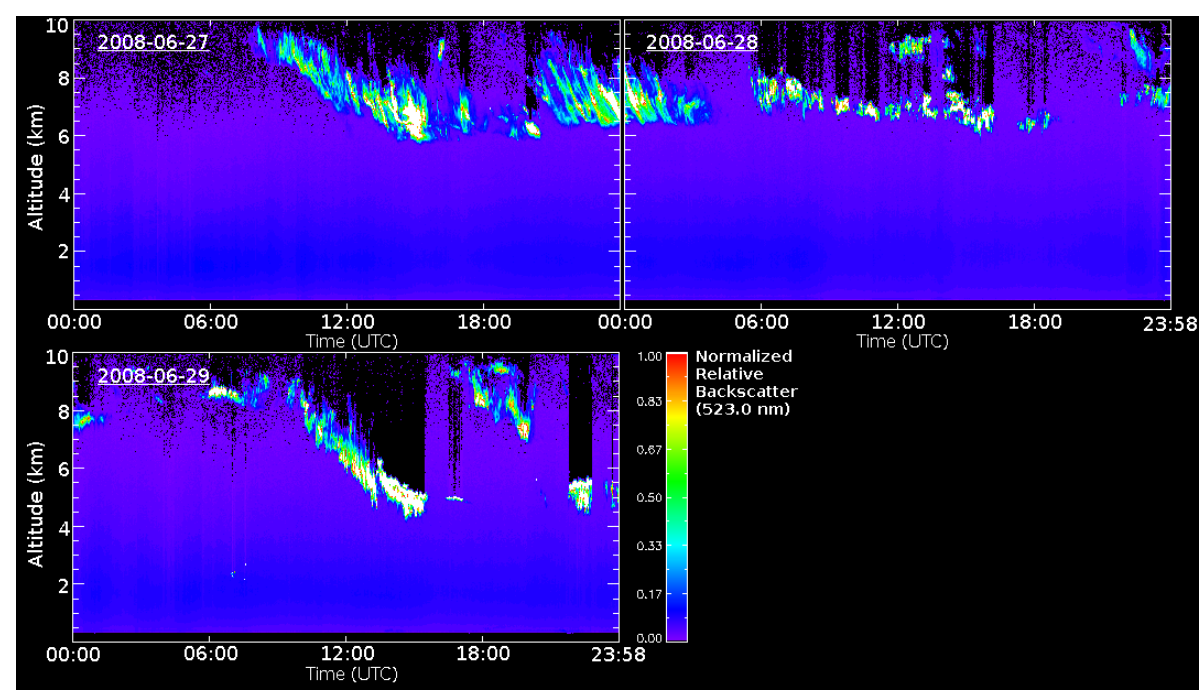

Figure 3. Normalized relative backscatter (Level 1.0 data) based on lidar measurements at Ny-Ålesund recorded during the period 27-29 June 2008 (modified from http://mplnet.gsfc.nasa.gov/).

al., 2013), and that conditions are favourable for new particle formation during the period of midnight sun. Integrated precipitation over the 5-day duration was calculated for each hourly trajectory. Over all there was little precipitation during the investigated periods with a median of less than $3.7 \mathrm{~mm}$ for the June case and less than $1.7 \mathrm{~mm}$ for the August case. The maximum integrated precipitation is an isolated event for a trajectory arriving 06:00 on 27 June. For this trajectory the integrated precipitation was $18.5 \mathrm{~mm}$. From this we can conclude that recent precipitation within the last 5 days was not likely a dominant factor in shaping the aerosol properties during transport.

From midday on 29 June 2008 until approximately 22:30 on that day, the total particle number concentrations of particles with diameters greater than $3 \mathrm{~nm}$ increased approximately from 400 to $3860 \mathrm{~cm}^{-3}$ (Fig. 2b). The highest concentrations were found for particles with diameters between 30 and $70 \mathrm{~nm}$. A change in the height pattern of the trajectories is seen between the midday of the 29 June and the following hours (Fig. 2). It seems that the air masses' height is reduced, and it is possible that this change in transport pattern resulted in more moisture supply to the air mass which helped promote particle formation and growth when the sun was at its highest.

To place the period in which the size-resolved CCN measurements were conducted in a long-term context, the median of the total particle number concentration for particles with diameters greater than $10 \mathrm{~nm}$ during this period is compared with the medians of the June data for the years 2001-2010 (Tunved et al., 2013). The long-term data have a time resolution of $1 \mathrm{~h}$, but around $9 \%$ of these data are missing or are of poor quality and are therefore not considered in the calculation. The data are available within specific size distributions, and the total number was calculated by integrating over the distinct size ranges. From 2001 to 2005 the lowest measured size was 17.8 and the largest was $707.9 \mathrm{~nm}$. From 2006 to 2007 a size bin with a lower measurement range of $13.8 \mathrm{~nm}$ was added. For 2008-2010, the size distribution diameter range was again broadened, to range between 10 and $790 \mathrm{~nm}$. The calculations resulted in a median particle number concentration of $177 \mathrm{~cm}^{-3}$ for 2001-2010, with a 25th percentile of $80 \mathrm{~cm}^{-3}$ and a 75 th percentile of $339 \mathrm{~cm}^{-3}$. The median values with 25 th percentile and 75 th percentile for the period during which our CCN size-resolved measurements were conducted during June 2008 are 245, 195 and $292 \mathrm{~cm}^{-3}$, respectively. Although the median total particle number concentration is somewhat $40 \%$ higher than the averaged June data from 2001 to 2010, it falls within the 75th percentile of the long-term data. This in combination with the low particle concentrations in the accumulation mode and the occurrence of a nucleation event indicates that the case study data from June 2008 can be regarded as relatively representative.

Particle number size distributions from 21 to 25 August 2008 are presented in Fig. 4a. In this figure, the purple vertical lines indicate the start and end times for the CCN sizeresolved concentration measurements. Difficulties with the DMPS measurements occurred approximately from 08:00 to 19:30 on 21 August and for short periods on 22 August; these time periods are omitted from the analysis. Time series of total particle number concentrations with dry diameters greater than 3 and $10 \mathrm{~nm}$ are showin in Fig. 4b. As with the measurements from June 2008, different periods with different characteristic particle number size distributions can be distinguished during the studied time period in August 2008 (Fig. 4a): (i) the final hours of 21 August, when particle number concentrations were highest for particles with diameters between 100 and $200 \mathrm{~nm}$; (ii) the early morning hours of 


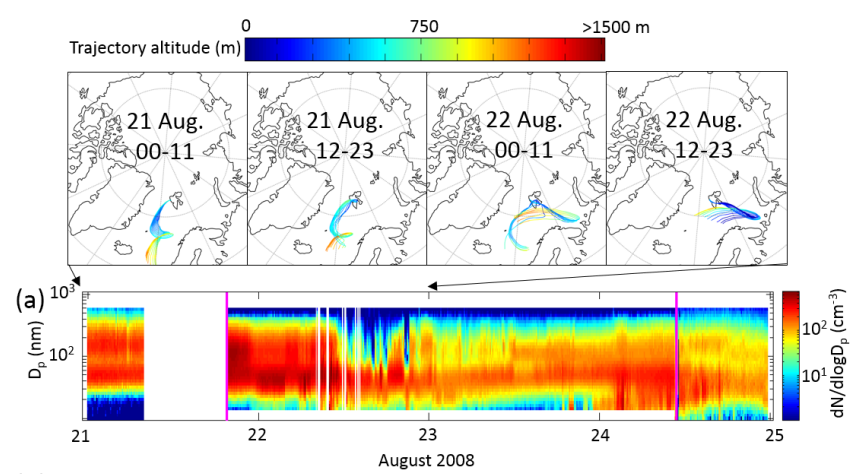

(b)

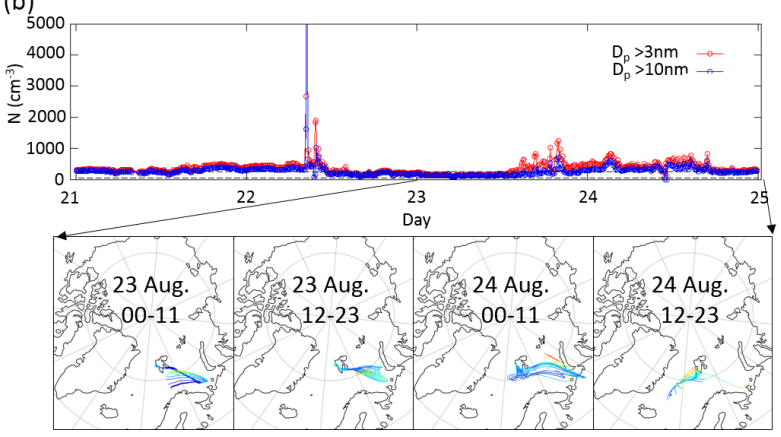

Figure 4. (a) Particle number size concentration measured before, during and after the size-resolved $\mathrm{CCN}$ concentration measurements were conducted in August 2008. Purple vertical lines indicate the start and end time of the $\mathrm{CCN}$ size-resolved concentration measurements. (b) Time series of the 8 min medians from CPC measurements for the same period in August 2008. Horizontal dashed lines represent the 25th and 75th percentile of the $\mathrm{CN}$ number concentration for August during the years 2001 to 2010. Trajectory plots show 5-day backward trajectories, calculated for every hour. Trajectory plots on top of panel (a) show air masses arriving between the 21 and 23 August 2008 at the Zeppelin research station. Trajectory plots below panel (b) show air masses arriving between midnight of the 23 August to midnight of the 24 August at the Zeppelin research station.

23 August, when particle number concentrations were relatively low for all measured sizes (cf. Fig. 4b) and (iii) during the first half of 24 August, when total aerosol concentrations were relatively high for the period, but no particular size range clearly dominated. Calculated 5-day backward trajectories for each hour indicate that air masses arriving on the 21 August at the Zeppelin station mainly come from the southern part of the Norwegian Sea (Fig. 4). Air masses arriving from the 22 August until midday the 24 August at the Zeppelin station have a more northern origin, the Barents Sea air masses arriving between midday and midnight on $24 \mathrm{Au}-$ gust at the Zeppelin station have again an origin over the Norwegian Sea.

As with the measurement period in June 2008, lidar data were consulted to investigate any local effects from clouds and precipitation (cf. Fig. 5). During the 21 August 2008, apparently clouds are present approximately between 0.7 and $9 \mathrm{~km}$ above the Zeppelin station. However, no precipitation reaching the station level could be detected. On $22 \mathrm{Au}-$ gust low clouds (altitude $<2 \mathrm{~km}$ ) were observed from approximately 09:00, and precipitation started at approximately 24:00, continuing until approximately 09:00. Only a few precipitation events are observed on 23 August 2008 for the most part, no clouds are observed at the altitudes above the Zeppelin station. On 24 August, clouds were only observed in Ny-Ålesund at altitudes higher than $0.8 \mathrm{~km}$.

From around 20:00 to 23:00 on 21 August 2008, particles with dry diameters between 100 and $200 \mathrm{~nm}$ dominate the particle number size distribution. During the time period of 02:00 and 24:00 on 21 August, the Zeppelin research station was, according to the lidar measurements, very likely unaffected by clouds. The trajectories of the 21 August show that air masses originate from the mid-latitudes and lower their height when reaching the Zeppelin research station (Fig. 4). Therefore, it is likely that the peak in the particle number size distribution for particles with diameters between 100 and $200 \mathrm{~nm}$ is a result of particles being transported from the midlatitudes to the Arctic and the processes taking place during transport rather than particles are being produced locally. The accumulation mode-dominated size distribution differs somewhat from the typical summer conditions. Tunved et al. (2013) demonstrated from their long-term average, during June-August, which locally produced particles with diameters in the nucleation and Aitken mode dominate the particle number size distribution. In the morning hours of $23 \mathrm{Au}-$ gust 2008, air masses arriving at the Zeppelin station originated in the Barents Sea (Fig. 4) and resulted in relatively low total particle concentrations, compared to the concentrations observed between 20:00 and 23:00 on 21 August 2008 (Fig. 2b). Air masses in the morning of 24 August originated as well in the Barents Sea, but result in higher total particle concentrations than observed on 23 August.

To place our second case study data in a long-term context, we compare median values of August 2008 with the 10year climatology presented by Tunved et al. (2013). Approximately $12 \%$ of the hourly data were excluded from calculations of the median integrated particle number concentration from 2001 to 2010 August, owing to them being either missing or of poor quality. The calculations produced a median particle number concentration of $127 \mathrm{~cm}^{-3}$ for August during 2001-2010, with a 25th percentile of $58 \mathrm{~cm}^{-3}$ and a 75th percentile of $252 \mathrm{~cm}^{-3}$. In comparison, the median values with 25 th percentile and 75 th percentile for the sizeresolved CCN measurement period in August 2008 are 226, 147 and $329 \mathrm{~cm}^{-3}$, respectively. Although, the total particle number concentration during the period in which the $\mathrm{CCN}$ size-resolved measurements were conducted is about $80 \%$ higher than the long-term average, the particle number concentration still falls within the 75th percentile.

Overall, the June case is similar to the long-term climatology and appears to be more representative of the summer period, with air masses of Arctic origin. In contrast, the Au- 


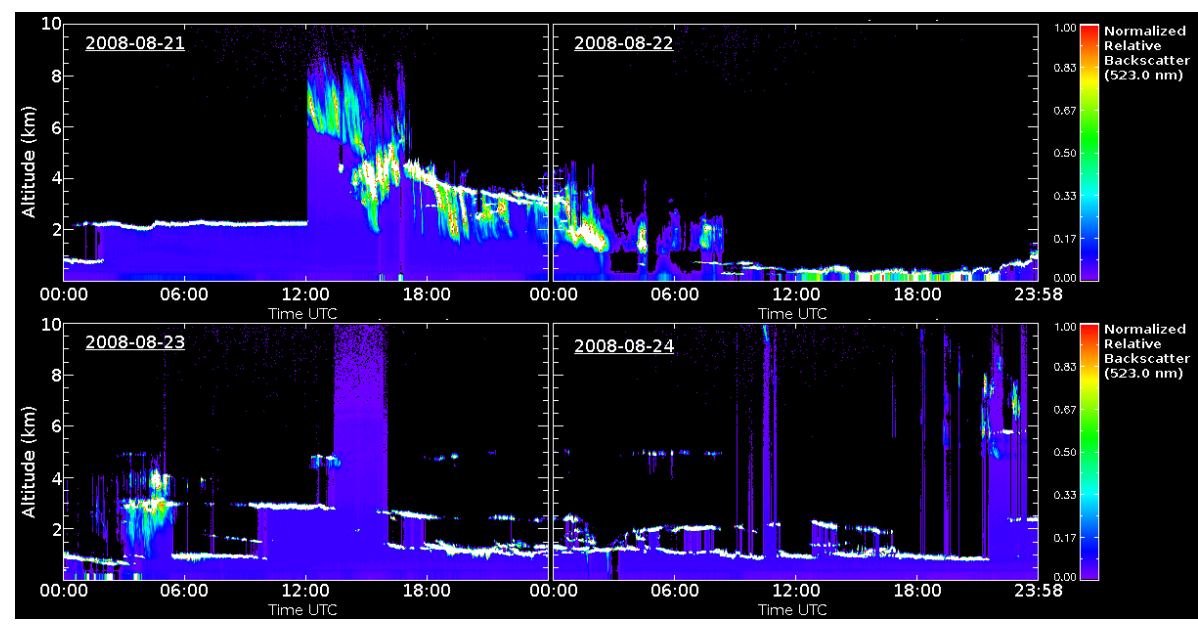

Figure 5. Normalized relative backscatter (Level 1.0 data) based on lidar measurements at Ny-Ålesund recorded during the period 2124 August 2008 (modified from http://mplnet.gsfc.nasa.gov/).

gust case differs more from the long-term climatology and shows a more significant influence of lower latitudes and higher number densities of accumulation particles.

\subsection{CCN spectra}

A CCN spectrum for a $5 \mathrm{~h}$ long period on the 27 June 2008 was obtained before the size-resolved $\mathrm{CCN}$ measurements were begun. The data presented in this section comprise medians calculated from one SS scanning cycle. The ratio, as a function of SS, between CCN number concentration and the total particle number concentrations for particles with diameters greater than $3 \mathrm{~nm}\left(\mathrm{CN}_{>3 \mathrm{~nm}}\right)$ for 27 June 2008 is shown in Fig. 6a. A significant increase in the ratio of CCN to $\mathrm{CN}$ with an increase in SS is detectable by applying the two-sample Kolmogorov-Smirnov test, only for an increase in SS from 0.2 to $0.4 \%$. The absolute number of CCN dependent on SS is shown for 27 June 2008 in Fig. 6b. Applying the two-sample Kolmogorov-Smirnov test to the data resulted in a significant difference in $\mathrm{CCN}$ numbers with increasing SS (5\% significance level). The power-law function, $N_{\mathrm{CCN}}(\mathrm{SS})=C \times \mathrm{SS}^{k}$, describing the number of $\mathrm{CCN}$ $\left(N_{\mathrm{CCN}}\right)$ with the coefficients $C$ and $k$ and SS, was fitted to the data shown in Fig. $6 \mathrm{~b}$ and giving values for the coefficients of $C=221$ and $k=0.482$. Ranges in the parameters $C$ and $k$ depend on the type of air mass, and the values for 27 June 2008 will be discussed in a later section, in combination with the values obtained from the August 2008 data.

$\mathrm{CCN}$ spectra obtained during 17 and $13 \mathrm{~h}$ observation periods on 21 and 24 August 2008, respectively, are shown on the right side of Fig. 6. The ratios between $\mathrm{CCN}$ and $\mathrm{CN}$ as a function of SS are shown in Fig. 6c for the two different days. For 21 August, a significant increase in the $\mathrm{CCN}$ to $\mathrm{CN}$ ratio with an increase in SS was observed in all cases. For $24 \mathrm{Au}-$ gust, the increase in ratio was significant for all increases in SS, except for the increase from 0.4 to $0.6 \%$ SS. The absolute
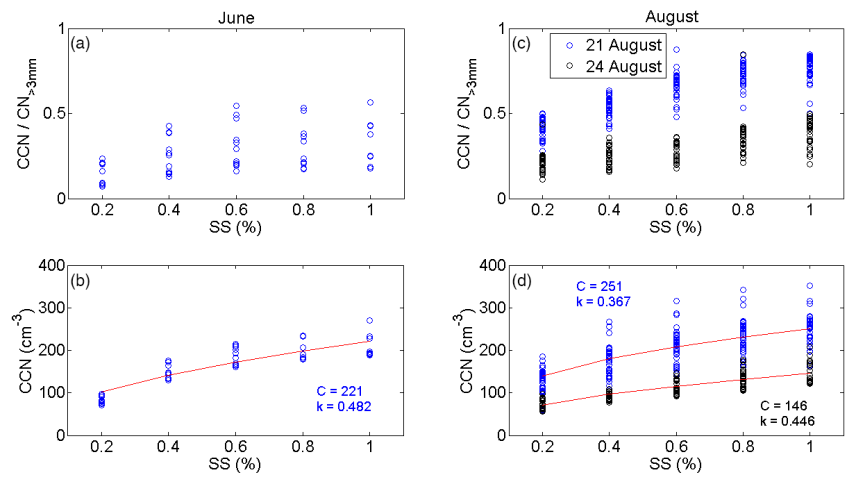

Figure 6. (a) Ratios of the medians for each SS scan between $\mathrm{CCN}$ and particles with diameters $>3 \mathrm{~nm}\left(\mathrm{CN}_{>3 \mathrm{~nm}}\right)$ for June 2008 as a function of SS. (b) Medians for each SS scan of the total numbers of CCN as a function of SS for June 2008. (c) Ratios of the medians for each SS scan between CCN and particles with diameters $>3 \mathrm{~nm}$ $\left(\mathrm{CN}_{>3 \mathrm{~nm}}\right)$ for 21 and 24 August 2008 as a function of SS. (d) Medians for each SS scan of the total numbers of $\mathrm{CCN}$ as a function of SS for 21 and 24 August 2008. The red curves represent power-law function fits to the data with the coefficients $C$ and $k$.

number of $\mathrm{CCN}$ for 21 and 24 August, as a function of SS, is shown in Fig. 6d. For both days, the increase in $\mathrm{CCN}$ number from one SS to the next is significant. This is based on applying the two-sample Kolmogorov-Smirnov test with a $5 \%$ significance level. As with the same data from 27 June 2008 (cf. Fig. 6b), a power-law function of the same form was fitted to the data from 21 and 24 August 2008, as denoted by the red lines in Fig. 6d. The fittings resulted in $C=251$ and $C=146$ and $k=0.367$ and $k=0.446$ for 21 and 24 August 2008, respectively.

Rogers and Yau (1996) demonstrated that the coefficients for maritime air vary, with $C=30-300 \mathrm{~cm}^{-3}$ and $k=$ $0.3-1.0$, while for continental air the values vary between 
$C=300-3000 \mathrm{~cm}^{-3}$ and $k=0.2-2.0$. The coefficients $C$ and $k$ that are given by the fitted power-law function applied to the measurements during June and August 2008 (cf. Fig. $6 \mathrm{~b}$ and d) are consistent with the ranges that Rogers and Yau (1996) proposed for maritime air masses. Pruppacher and Klett (2010) also presented a compilation of $C$ and $k$ values from different studies, alongside the $\mathrm{CCN} / \mathrm{CN}$ ratio for a SS of $1 \%$ at different locations, characterized by either maritime or continental air masses. Only one study from the Arctic, influenced by a maritime air mass, is presented, providing a $C$ value between 100 and $1000 \mathrm{~cm}^{-3}$. Pruppacher and Klett (2010) did not present a $\mathrm{k}$ value for this study, but stated that the $\mathrm{CCN} / \mathrm{CN}$ at $1 \% \mathrm{SS}$ is 0.5 . Compared to the data from the Zeppelin station in this study, this range is at the lower limit of that observed on 21 August 2008, and at the upper limit of that observed on 27 June and $24 \mathrm{Au}$ gust 2008 (cf. Fig. 6a and c). However, it should be noted that direct comparison is difficult as it is not known which size range was considered for the integrated number of $\mathrm{CN}$. Hegg et al. (1995) also presented a number of $C$ and $k$ values and $\mathrm{CCN} / \mathrm{CN}$ ratios obtained during several flight campaigns over the Arctic. Although an increase in $\mathrm{CCN}$ was observed with an increase in altitude for a SS of $1 \%, \mathrm{CCN}$ concentrations for altitudes $<1.6 \mathrm{~km}$ were always lower than $100 \mathrm{~cm}^{-3}$. This is in contrast to the measurements obtained at the Zeppelin station in this study, where CCN concentrations were generally higher than $100 \mathrm{~cm}^{-3}$ at a SS of $1 \%$ (cf. Fig. $6 \mathrm{~b}$ and c). The average $\mathrm{CCN} / \mathrm{CN}$ ratio for measurements conducted at altitudes lower than $1.6 \mathrm{~km}$ was calculated to be 0.15 (Hegg et al., 1995), which is lower than the calculated average ratios of $0.32,0.77$ and 0.38 obtained for a SS of $1 \%$ for 27 June, 21 and 24 August 2008.

Yum and Hudson (2001) estimated an average CCN concentration of $76 \mathrm{~cm}^{-3}$ in conditions when low clouds are present and an average of $250 \mathrm{~cm}^{-3}$ for non-cloudy conditions at a SS of $0.8 \%$. Estimating the $\mathrm{CCN}$ concentration at $0.8 \%$ SS with the power-law function results in CCN concentrations of 199, 231 and $132 \mathrm{~cm}^{-3}$ for 27 June, 21 and 24 August, respectively. For 27 June only high clouds (altitude $>5 \mathrm{~km}$ ) were present, while for 21 and 24 August clouds were observed at altitudes higher than $0.7 \mathrm{~km}$ (cf. Sect. 3.1). The CCN concentrations calculated herein using the power law relation and a SS of $0.8 \%$ for June and August clearly lies between those $\mathrm{CCN}$ concentrations determined by Yum and Hudson (2001) for non-cloudy conditions. The $\mathrm{CCN} / \mathrm{CN}$ ratio calculated by Yum and Hudson (2001) is 0.65 at a SS of $0.8 \%$, which is higher than the average ratio determined for the $\mathrm{CCN}$ spectra during 27 June and $24 \mathrm{Au}$ gust 2008. The arithmetic means of the $\mathrm{CCN} / \mathrm{CN}$ ratio at a SS of $0.8 \%$ are $0.31,0.75$ and 0.35 for 27 June, 21 and 24 August 2008, respectively. Yum and Hudson (2001) also present altitude-dependent $k$ values for a SS range of $0.1-$ $0.6 \%$. The $k$ values for cloudy conditions ranged between 0.27 and 0.55 and between 0.34 and 0.75 for non-cloudy conditions. Calculated $k$ values for 27 June, 21 and $24 \mathrm{Au}$ - gust 2008, only considering a SS range of 0.2 to $0.6 \%$, were found to be $0.65,0.41$ and 0.37 , which is similar to the results obtained by Yum and Hudson (2001).

Silvergren et al. (2014) presented CCN number concentrations as a function of SS and as a function of the month from September 2007 to August 2008, calculated based on aerosol collections on filters at the Zeppelin research station. For June 2008, a CCN number concentration of around $100 \mathrm{~cm}^{-3}$ at a SS of $0.4 \%$ is shown. This concentration is lower than the calculated $\mathrm{CCN}$ number concentration found here using the power-law relation shown in Fig. 6 and a SS of $0.4 \%$, which results in a CCN number concentration of $142 \mathrm{~cm}^{-3}$. For August 2008, Silvergren et al. (2014) calculated a CCN number concentration of approximately $65 \mathrm{~cm}^{-3}$ at $0.4 \% \mathrm{SS}$ for the the Zeppelin research station, which is although lower than the concentrations of 179 and 97 particles $\mathrm{cm}^{-3}$ calculated from the presented data in Fig. 6d for 21 and 24 August 2008.

No clear separation can be made between the two CCN spectra from August 2008 and the one CCN spectrum from June 2008. In general, the CCN spectrum of June 2008 (Fig. 6b) lies between the two different spectra of $\mathrm{Au}-$ gust 2008 (Fig. 6d). Comparing backward trajectories arriving at the Zeppelin before midday the 27 June (Fig. 2) and before midday the 21 August and after midday the 24 August (Fig. 4), corresponding to the times when the CCN spectra were measured, show that the air masses' origin was for the most of the times southerly of Svalbard. However, even those air masses with similar origins can show differences in their aerosol characteristics (Park et al., 2014).

\subsection{CCN activation diameter}

The size-resolved activation of particles having $D_{\mathrm{p}}$ between 15 and $400 \mathrm{~nm}$ at $0.4 \%$ SS is shown in Fig. 7. The upper panel shows the geometric mean of the activated particle concentration measured by the CCNC compared to the geometric mean of the total particle $(\mathrm{CN})$ concentration measured by the CPC for the measurement period during June 2008 (Fig. 7a). The lower panel shows the correspondent data for the measurement period in August 2008 (Fig. 7b). The most distinct differences between the particle number concentrations of total particles measured by the CPC during the experimental period in June 2008 and August 2008 is (a) a higher particle number concentration having $D_{\mathrm{p}}<20 \mathrm{~nm}$ during June; (b) a peak of particle concentration at approximately $D_{\mathrm{p}} 50 \mathrm{~nm}$ in August and (c) a higher variation in particle concentration for the different size bins indicated by a higher geometric SD during August compared to June. As the $\mathrm{CN}$ number concentration, the $\mathrm{CCN}$ concentration is characterized by a higher variability during the measurement period in August compared to the measurement period in June.

To establish the presented study contextually with other studies, the ratio between $\mathrm{CCN}$ and $\mathrm{CN}$ as a function of dry particle diameter was calculated (Fig. 8). Note that dur- 

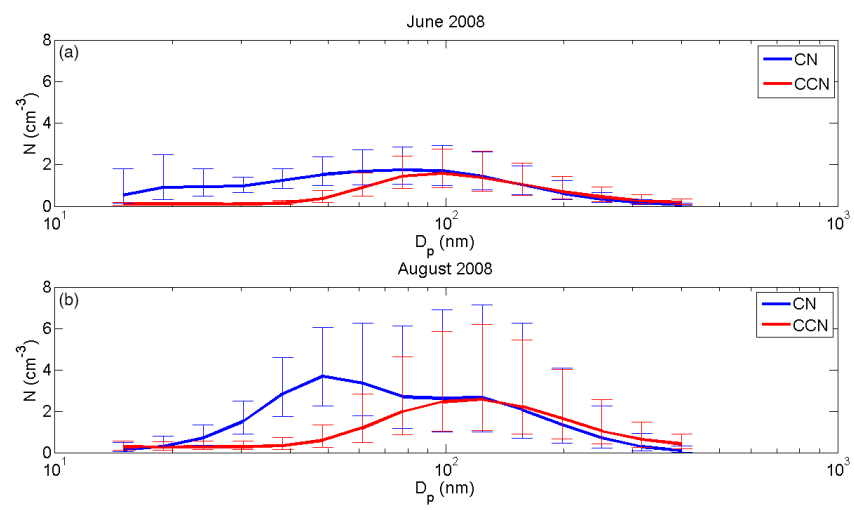

Figure 7. Geometric means of size-resolved particle density measurements and resulting $\mathrm{CCN}$ concentrations for the measurement period in (a) June 2008 and (b) August 2008. Measurements were conducted at $0.4 \%$ SS. Error bars indicate the geometric standard deviation.

ing June the $\mathrm{CCN}$ concentration exceeds the total particle concentration for $D_{\mathrm{p}}>156 \mathrm{~nm}$, and during August the $\mathrm{CCN}$ concentration is higher than the $\mathrm{CN}$ concentration for $D_{\mathrm{p}}<19 \mathrm{~nm}$ and $D_{\mathrm{p}}>123 \mathrm{~nm}$. The experimental approach of selecting a narrow size range that can be applied to the CCNC results in very low particle concentrations in the instrument. In particular, for measurements made at either end of the size distribution, small errors can cause large changes in the ratio, as presented in Fig. 8. To obtain completeness, all data points are shown; however, the sizes where $\mathrm{CCN} / \mathrm{CN} \geq 1$ have been shaded and disregarded.

After applying a spline interpolation to the measurement data, the dry diameter at which $50 \%$ of the total particle number concentration was activated $\left(D_{50}\right)$ was calculated to be $60 \mathrm{~nm}$ for the measurement period in June 2008 and $67 \mathrm{~nm}$ in August 2008. To the best of our knowledge, to date no sizeresolved CCN measurements in the Arctic have been published; therefore, data are compared to results obtained in the subarctic. Anttila et al. (2012) reported a study that was conducted at the Finnish Pallas-Sodankylä Global Atmospheric Watch station that measured the ratio between cloud droplet number concentration and total particle concentration while the station was in clouds as a function of dry particle size. By comparing CCN concentrations at a fixed SS of $0.4 \%$ with cloud droplet number concentrations, it was concluded that during the cloud events the "effective" maximal SS was likely to be approximately $0.4 \%$ in most cases. During the five periods when the station was in clouds, $D_{50}$ varied between 80 and $102 \mathrm{~nm}$ on average. A comparable study at the same measurement site resulted in $D_{50}$ between 110 and $140 \mathrm{~nm}$ for maximal SS between 0.18 and $0.26 \%$ (Anttila et al., 2009). Komppula et al. (2005) calculated $D_{50}$ by comparing a particle number size distribution measured at a site in clouds with a nearby measured size distribution obtained at a station under cloud-free conditions. $D_{50}$ was estimated

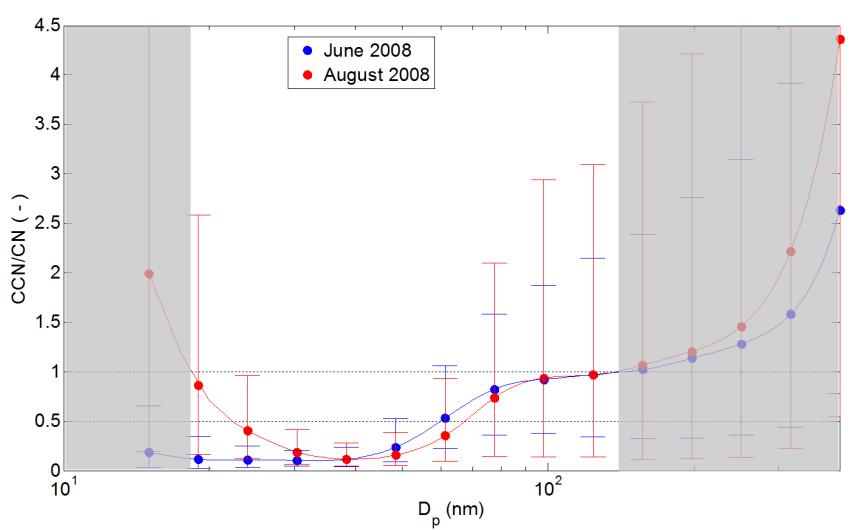

Figure 8. Activation ratio as a function of dry particle diameter $\left(D_{\mathrm{p}}\right)$ for the measurement period in June 2008 and August 2008. Obtained from measurements at a SS of $0.4 \%$. Error bars indicate $\mathrm{SD}$. The grey area indicates the for further analysis omitted data.

to be $80 \mathrm{~nm}$ on average and varied between 50 and $128 \mathrm{~nm}$. Unfortunately, the SS is unknown. Due to the uncertainty in SS, it is not possible to compare present study to the studies conducted at the Finnish stations directly. However, due to SS lower than $0.4 \%$ reported by Anttila et al. $(2012,2009)$, larger activation diameters in these studies compared to this study are expected, which is in line with the presented results. Jaatinen et al. (2014) report activation diameters for measurements conducted during the same field campaign as reported in Anttila et al. (2012). However, compared with Anttila et al. (2012), in the present study, activation diameters were calculated differently and for a shorter period. The critical diameter was calculated by interpolating between the size bin at which the integrated particle number size distribution was equal to the amount of total measured $\mathrm{CCN}$ and the previous size bin. This resulted in a critical diameter of $98 \pm 16 \mathrm{~nm}$ for $0.4 \%$ SS (Jaatinen et al., 2014).

Besides SS, the chemical composition and mixing state determines the ability of particles to become activated to cloud droplets (Frosch et al., 2011; M. J. K. Moore et al., 2011; Ervens et al., 2010; Sullivan et al., 2009). Kreidenweis et al. (2005) summarize results of predicted and experimentally determined critical diameters of ammonium sulphate and sodium chloride particles. Predicted critical diameters for sodium chloride particles vary between 44.6 and $39.4 \mathrm{~nm}$ (Kreidenweis et al., 2005 and references therein) and the experimentally determined diameter for a SS of $0.4 \%$ was reported to be $40 \pm 6 \mathrm{~nm}$ (Corrigan and Novakov, 1999 in Kreidenweis et al., 2005). Ammonium sulphate particles had larger predicted activation diameters at SS of $0.4 \%$, i.e., from 62.6 to $49 \mathrm{~nm}$ (Kreidenweis et al., 2005 and references therein). Experimentally determined critical diameters of ammonium sulphate were $51 \pm 8$ and $59 \pm 9 \mathrm{~nm}$ (Corrigan and Novakov, 1999 and Pradeep Kumar et al., 2003 in Kreidenweis et al., 2005). Corrigan and Novakov (1999) experimentally estimated $D_{50}$ measured at a SS of $0.4 \%$ to 
be $82 \mathrm{~nm}, 148$ and $74 \mathrm{~nm}$ for succinic acid, adipic acid and glucose aerosols, respectively. It was concluded that all $D_{50}$ match well with the $D_{50}$ calculated theoretically, except for the less soluble adipic acid. Pradeep Kumar et al. (2003) experimentally determined the activation diameter of oxalic acid to be $65 \mathrm{~nm}$ at a SS of $0.40 \%$. In the following section, the obtained information of the activation diameter, as well as the chemical information about the aerosol at the Zeppelin research station from another study are used to calculate the hygroscopicity parameter $\kappa$.

\subsection{Comparison of $\kappa$ values obtained with different methods}

The hygroscopicity parameter $\kappa$ was first introduced by Petters and Kreidenweis (2007) to describe the relationship between particle dry diameter and CCN activity. In this study, $\kappa$ values were calculated with two independent approaches for June and August 2008: (1) based on the CCN activation of the aerosol population; (2) based on the bulk chemical composition of the particulate mass sampled at the site.

First, the relationship between the activation diameter $\left(D_{\mathrm{p}, \text { act }}\right)$ and SS derived from $\kappa$-Köhler theory (Asa-Awuku et al., 2010) was applied to the experimental CCN data:

$\mathrm{SS}=\frac{2}{3}\left[\frac{4 M_{\mathrm{w}} \sigma}{R T \rho}\right]^{\frac{3}{2}}\left(3 \kappa D_{\mathrm{p}, \text { act }}^{3}\right)^{\frac{-1}{2}}$,

where $M_{\mathrm{W}}\left(\mathrm{kg} \mathrm{mol}^{-1}\right)$ is the molar mass of water, $T$ is the temperature, $R$ is the universal molar gas constant, $\sigma$ is the surface tension of the solution/air interface and $\rho\left(\mathrm{kg} \mathrm{m}^{-3}\right)$ is the density of the solution. The surface tension of pure water $0.072 \mathrm{~J} \mathrm{~m}^{2}$ and the density of pure water $1000 \mathrm{~kg} \mathrm{~m}^{-3}$ were applied. Temperature was assumed to be $295 \mathrm{~K}$ to match the temperature in the instruments. When analysing the experimental data, the activation diameter was assumed to be the dry diameter corresponding to the $\mathrm{CCN}$ to $\mathrm{CN}$ ratio of 0.5 . However, we tested the sensitivity to this assumption by repeating the calculations for $\mathrm{CCN} / \mathrm{CN}$ values of 0.25 and 0.75 . The resulting $\kappa$ values were $0.2-0.7$ for June and $0.2-$ 0.5 for August, with the best estimates (corresponding to the $50 \%$-points in the $\mathrm{CCN} / \mathrm{CN}$ ratios) of 0.4 and 0.3 , respectively (Table 1).

Second, the $\kappa$ values derived from the $\mathrm{CCN}$ activation data were compared to $\kappa$ values obtained using the aerosol composition data. In this case, the total $\kappa$ for the multi-component aerosol particles was calculated using the simple mixing rule

$\kappa=\sum_{i} \varepsilon_{i} \kappa_{i}$,

where $\varepsilon_{i}$ and $\kappa_{i}$ are the volume fraction and hygroscopicity parameter of each component $i$, respectively (Petters and Kreidenweis, 2007). We assumed internally mixed aerosol particles, composed of four surrogate components (inorganics, more water-soluble organics, less water-soluble organics and elemental carbon, similar to Rastak et al., 2014; see
Table 2 for the assumed single-component properties). The monthly mass fractions of the organic components were estimated by analysing filter samples of particles that passed a $\mathrm{PM}_{10}$ inlet. The inorganic fraction was determined after sampling the aerosol with an open face system without a $\mathrm{PM}_{10}$ inlet but shielded with a cylinder that reduced the sampling efficiency for particles larger than $10 \mu \mathrm{m}$ (Silvergren et al., 2014). It should be noted that the properties of ammonium sulphate were used to describe the inorganic fraction. The sea salt contribution in the inorganic fraction was not considered for particles less than $400 \mathrm{~nm}$ (upper bound of the DMPS in this study). The resulting total $\kappa$ values were approximately 0.5 for both considered months (Table 2).

Comparison of the "bulk $\kappa$ " (obtained with Eq. 2 and bulk chemical composition) with the "CCN $\kappa$ " (obtained from the $\mathrm{CCN} / \mathrm{CN}=0.50$ point with Eq. 1) shows reasonable agreement for June but a slight overestimation for August. This could be due to the overestimation of the inorganic fraction in the "bulk $\kappa$ ", as particles with diameters $>400 \mathrm{~nm}$ were also able to reach the filter. The chemical composition was therefore probably not accurately representative of the $\mathrm{CCN}$ sized particles. In addition, it should be noted that the data used to calculate $\kappa$ with Eq. (1) are based on only 2-3 days of measurements during June and August 2008 while the calculations used in Eq. (2) are based on bulk aerosol properties over the whole month of June and August 2008.

Silvergren et al. (2014) used three different approaches to calculate $\kappa$ for June 2008 and August 2008. Bulk aerosol samples on filters were obtained during June and August 2008 at the Zeppelin research station. The filters were extracted and the extract was again filtered so that only the water-soluble fraction of the aerosols remained. With the first two approaches, particles were generated by an atomizer and then measured in a Hygroscopic Tandem Differential Mobility Analyser (HTDMA) and a CCNC. The corresponding $\kappa$ values were calculated based on determined growth factors and critical SS and were estimated to be approximately between 0.4 and 0.5 on an average for both June and August 2008. In the third method, Silvergren et al. (2014) used the chemical information from the filter samples in combination with literature values to determine the activation diameter and the critical SS based on Köhler theory. The resulting $\kappa$ values were approximately 0.7 for both June and August 2008 (cf. Fig. 9 in Silvergren et al., 2014). In present study, the "CCN $\kappa$ " value for June was 0.4 , which is in the lower end of results reported by Silvergren et al. (2014). For August, "CCN $\kappa$ " was 0.3 , which is lower than the results presented by Silvergren et al. (2014). The "bulk $\kappa$ " values determined here are within the ranges determined by Silvergren et al. (2014) based on HTDMA and CCNC measurements.

Based on aerosol optical properties, Zieger et al. (2010) determined a mean $\kappa$ value of 0.6 for the period July to October 2008 at the Zeppelin research station. The value presented by Zieger et al. (2010) is somewhat higher than the "bulk $\kappa$ " estimated in this study ( 0.5 for both months). 
Table 1. Measured diameters when $\mathrm{CCN} / \mathrm{CN}=0.25,0.50$ and 0.75 and corresponding calculated $\kappa$ values with Eq. (1).

\begin{tabular}{rrrrrr}
\hline & \multicolumn{4}{c}{ June } & \multicolumn{3}{c}{ August } \\
\cline { 2 - 6 } & Activation diameter $(\mathrm{nm})$ & $\kappa$ & Activation diameter $(\mathrm{nm})$ & $\kappa$ \\
\hline $\mathrm{CCN} / \mathrm{CN}=0.25$ & 49 & 0.7 & 56 & 0.5 \\
$\mathrm{CCN} / \mathrm{CN}=0.50$ & 60 & 0.4 & 67 & 0.3 \\
$\mathrm{CCN} / \mathrm{CN}=0.75$ & 72 & 0.2 & 78 & 0.2 \\
\hline
\end{tabular}

Table 2. Experimentally derived mass fractions (Silvergren et al., 2014), densities $\rho$ and $\kappa_{i}$ values for each component used for the total $\kappa$ calculations (Rastak et al., 2014 and references therein). Properties of ammonium sulphate were assumed for the inorganic fraction.

\begin{tabular}{lrrrr}
\hline Component & $\begin{array}{r}\text { Mass fraction (\%) } \\
\text { June }\end{array}$ & $\begin{array}{r}\text { Mass fraction }(\%) \\
\text { August }\end{array}$ & $\begin{array}{r}\rho \\
\left(\mathrm{kg} \mathrm{m}^{-3}\right)\end{array}$ & $\kappa_{i}$ \\
\hline inorganics & 88 & 90 & 1770 & 0.53 \\
more water-soluble organics & 10 & 7 & 1560 & 0.27 \\
less water-soluble organics & 2 & 2 & 1500 & 0.10 \\
elemental carbon & 1 & 1 & 1800 & 0.00 \\
\hline & & & & Total $\kappa$ \\
\hline June & & & & 0.5 \\
August & & & & 0.5 \\
\hline
\end{tabular}

Conversely, the $\kappa$ values calculated from the $D_{50}$ using the DMPS-CCNC combination are clearly lower $(0.4$ for June, and 0.3 for August).

The main reason for the differences between the present study and both Zieger et al. (2010) and Silvergren et al. (2014) is probably related to the influence of large (> $400 \mathrm{~nm}$ ) particles in determining $\kappa$ based on aerosol optical properties and the bulk chemical composition.

Anttila et al. (2012) reported a $\kappa$ value of approximately 0.1 at Pallas for the same period as he presented activation diameters (cf. Sect. 3.3). The presented $\kappa$ values are based on HTDMA measurements at $90 \%$ relative humidity for particles with $100 \mathrm{~nm} D_{d}$. Jaatinen et al. (2014) presented $\kappa$ values obtained during the same measurement campaign as Anttila et al. (2012). However, the hygroscopicity parameter was determined differently and for a shorter period. The $\kappa$ value derived by the critical diameter (cf. Sect. 3.3) for a SS of $0.4 \%$ was estimated to be approximately 0.1 and thus is in agreement with the HTDMA-based observations of particles with $100 \mathrm{~nm} D_{d}$ reported by Anttila et al. (2012). Conversely, the $\kappa$ calculated based on aerosol mass spectrometer (AMS) data collected approximately $6 \mathrm{~km}$ from the site of the CCN and HTDMA measurements was approximately 0.3 . The "CCN $\kappa$ " values determined in this study are higher than those obtained by Anttila et al. (2012) and Jaatinen et al. (2014). These differences can be explained by the different chemical composition of the aerosol population. Jaatinen et al. (2014) showed that at Pallas $47 \%$ of the measured mass concentration of the aerosols consisted of organic com- pounds, while at Zeppelin $90 \%$ of the aerosol mass was inorganic material and thus more hygroscopic material.

\section{Summary and conclusions}

For the first time, size-resolved $\mathrm{CCN}$ measurements in the Arctic have been reported. Measurements were conducted at the Zeppelin research station, Svalbard during two short periods in June and August 2008. A near-monodisperse aerosol having a $D_{\mathrm{p}}$ between 15 and $400 \mathrm{~nm}$ was selected by a DMA. The DMA was connected to a CCNC operating at $0.4 \% \mathrm{SS}$ and in parallel to a CPC 3010. Before and after the sizeresolved $\mathrm{CCN}$ measurements were taken, the CCNC was measuring the ambient air without previous selection of a monodisperse aerosol. During these periods, the SS in the CCNC was changed to $0.2,0.4,0.6,0.8$ and $1 \%$.

Trajectory analysis showed that during the measurement period in June 2008 air masses arriving at Zeppelin were dominated by Arctic air, while during August 2008 air masses originated from the Norwegian Sea and from the Barents Sea. A comparison of long-term June particle number size distributions with those registered during the sizeresolved CCN measurements in June 2008 showed that the size distribution characterized by a nucleation event and low particle concentrations for $D_{\mathrm{p}}<100 \mathrm{~nm}$ is representative for averaged conditions during June. In contrast, the particle number size distributions registered during August 2008 indicate long-range transport that differs from the long-term observations during August. In addition to the size-resolved $\mathrm{CCN}$ measurements, SS spectra were determined. In June, 
this was done directly before the size-resolved measurements were completed and in August directly before and after the size-resolved measurements were conducted. A powerlaw function of the form $N_{\text {ccn }}(\mathrm{SS})=C \times \mathrm{SS}^{k}$, with $N_{\text {ccn }}$ as the number of $\mathrm{CCN}$ and the coefficients $C$ and $k$, was fitted to the SS spectra. The coefficients for June were estimated to be $C=221$ and $k=0.482$. Coefficients for August were $C=251$ and $k=0.367$ before the size-resolved measurements were conducted and $C=146$ and $k=0.446$ after the size-resolved measurements were conducted. The spectra measured during June lies between the two measured during August. For a SS of $0.4 \%, \mathrm{CCN}$ number concentrations as a function of dry particle diameter were presented. From the size-dependent $\mathrm{CCN}$ measurements, $D_{50}$ (particle diameter where $\mathrm{CCN} / \mathrm{CN}=0.5$ ) was estimated. For the June 2008 measurement period, $D_{50}$ was $60 \mathrm{~nm}$, while for the August 2008 measurement period, $D_{50}$ was approximately $67 \mathrm{~nm}$. For the first time $\kappa$ values for the Arctic were calculated based on activation diameters obtained from in situ size-resolved $\mathrm{CCN}$ measurements, meaning the $\kappa$ values are based on a conserved chemistry of the particles. Values of the hygroscopicity parameter $\kappa$ were calculated to be 0.4 and 0.3 for June and August, respectively. Estimating $\kappa$ based on simplified bulk chemical properties that were observed in June and August (2008) gave a value of 0.5. The higher $\kappa$ value based on chemistry is likely explained by an enhanced influence of larger and more hygroscopic particles. It should be considered that, due to their lower numbers, these larger particles are less crucial for $\mathrm{CCN}$ activation. Therefore, the $\kappa$ values based on in situ measured size-resolved CCN measurements and growth factors are probably more meaningful in characterizing the ability of an aerosol population to become activated to cloud droplets. In future, it is needed to establish long-term size-resolved CCN measurements in the Arctic to study the size-dependent activation of particles for different seasons. An analysis of the difference in resulting $\kappa$ values with $\kappa$ values resulting from long-term chemistry analysis of the particles is needed to quantify and explain the reason for the differences and to point out possible differences to $\kappa$ to the cloud model community.

Acknowledgements. We would like to thank Peter Tunved for providing the DMPS and CPC data and for the help with trajectory calculation and plotting. We acknowledge that the $\mathrm{CCN}$ measurements were supported by the KOPRI project NRF-20110021063. The authors gratefully acknowledge the NOAA Air Resources Laboratory (ARL) for the provision of the HYSPLIT transport and dispersion model and the READY website (http://www.ready.noaa.gov) used in this publication. The Swedish Environmental Protection Agency (NV) is acknowledged for their financial support of measurements at the Zeppelin station. We would like to point out that the NASA Micro-Pulse Lidar Network is funded by the NASA Earth Observing System and Radiation Sciences Program. We thank the MPLNET PI Masataka Shiobara and MPLNET staff Kerstin Binder for their efforts in establishing and maintaining the lidar measurements at Ny-Ålesund. The CRAICC project and the Bolin Center for Climate Research are as well acknowledged.

Edited by: V.-M. Kerminen

\section{References}

Anttila, T., Vaattovaara, P., Komppula, M., Hyvärinen, A.-P., Lihavainen, H., Kerminen, V.-M., and Laaksonen, A.: Sizedependent activation of aerosols into cloud droplets at a subarctic background site during the second Pallas Cloud Experiment (2nd $\mathrm{PaCE}$ ): method development and data evaluation, Atmos. Chem. Phys., 9, 4841-4854, doi:10.5194/acp-9-4841-2009, 2009.

Anttila, T., Brus, D., Jaatinen, A., Hyvärinen, A.-P., Kivekäs, N., Romakkaniemi, S., Komppula, M., and Lihavainen, H.: Relationships between particles, cloud condensation nuclei and cloud droplet activation during the third Pallas Cloud Experiment, Atmos. Chem. Phys., 12, 11435-11450, doi:10.5194/acp12-11435-2012, 2012.

Asa-Awuku, A., Nenes, A., Gao, S., Flagan, R. C., and Seinfeld, J. H.: Water-soluble SOA from Alkene ozonolysis: composition and droplet activation kinetics inferences from analysis of CCN activity, Atmos. Chem. Phys., 10, 1585-1597, doi:10.5194/acp10-1585-2010, 2010.

Bhattu, D. and Tripathi, S. N.: Inter-seasonal variability in sizeresolved CCN properties at Kanpur, India, Atmos. Environ., 85, 161-168, 2014.

Bigg, E. K. and Leck, C.: Cloud-active particles over the central Arctic Ocean, J. Geophys. Res., 106, 32155-32166, 2001.

Boucher, O., Randall, D., Artaxo, P., Bretherton, C., Feingold, G., Forster, P., Kerminen, V.-M., Kondo, Y., Liao, H., Lohmann, U., Rasch, P., Satheesh, S. K., Sherwood, S., Stevens, B., and Zhang, X. Y.: Clouds and Aerosols, in: Climate Change 2013: The Physical Science Basis. Contribution of Working Group I to the Fifth Assessment Report of the Intergovernmental Panel on Climate Change, edited by: Stocker, T. F., Qin, D., Plattner, G.-K., Tignor, M., Allen, S. K., Boschung, J., Nauels, A., Xia, Y., Bex, V., and Midgley, P. M., Cambridge University Press, Cambridge, UK and New York, NY, USA, 2013.

Chang, R. Y.-W., Sjostedt, S. J., Pierce, J. R., Papakyriakou, T. N., Scarratt, M. G., Michaud, S., Levasseur, M., Leaitch, W. R., and Abbatt, J. P. D.: Relating atmospheric and oceanic DMS levels to particle nucleation events in the Canadian Arctic, J. Geophys. Res., 116, D00S03, doi:10.1029/2011JD015926, 2011.

Corrigan, C. E. and Novakov, T.: Cloud condensation nucleus activity of organic compounds: a laboratory study, Atmos. Environ., 33, 2661-2668, 1999.

Draxler, R. R. and Rolph, G. D.: HYSPLIT (HYbrid Single-Particle Lagrangian Integrated Trajectory), NOAA Air Resources Laboratory, Silver Spring, MD, USA, Model access via NOAA ARL READY Website: http://ready.arl.noaa.gov/HYSPLIT.php, last access: 7 August 2015.

Ervens, B., Cubison, M. J., Andrews, E., Feingold, G., Ogren, J. A., Jimenez, J. L., Quinn, P. K., Bates, T. S., Wang, J., Zhang, Q., Coe, H., Flynn, M., and Allan, J. D.: CCN predictions using simplified assumptions of organic aerosol composition and mix- 
ing state: a synthesis from six different locations, Atmos. Chem. Phys., 10, 4795-4807, doi:10.5194/acp-10-4795-2010, 2010.

Frosch, M., Prisle, N. L., Bilde, M., Varga, Z., and Kiss, G.: Joint effect of organic acids and inorganic salts on cloud droplet activation, Atmos. Chem. Phys., 11, 3895-3911, doi:10.5194/acp11-3895-2011, 2011.

Gunthe, S. S., King, S. M., Rose, D., Chen, Q., Roldin, P., Farmer, D. K., Jimenez, J. L., Artaxo, P., Andreae, M. O., Martin, S. T., and Pöschl, U.: Cloud condensation nuclei in pristine tropical rainforest air of Amazonia: size-resolved measurements and modeling of atmospheric aerosol composition and CCN activity, Atmos. Chem. Phys., 9, 7551-7575, doi:10.5194/acp-9-75512009, 2009.

Hegg, D. A., Ferek, R. J., and Hobbs, P. V.: Cloud Condensation Nuclei over the Arctic Ocean in Early Spring, J. Appl. Meteor., 34, 2076-2082, 1995.

Hegg, D. A., Hobbs, P. V., Gassó, S., Nance, J. D., and Rangno, A. L.: Aerosol measurements in the Arctic relevant to direct and indirect radiative forcing, J. Geophys. Res., 101, 23349-23363, 1996.

Hiranuma, N., Brooks, S. D., Moffet, R. C., Glen, A., Laskin, A., Gilles, M. K., Liu, P., Macdonald, A. M., Strapp, J. W., and McFarquhar, G. M.: Chemical characterization of individual particles and residuals of cloud droplets and ice crystals collected on board research aircraft in the ISDAC 2008 study, J. Geophys. Res.-Atmos., 118, 6564-6579, 2013.

Hoppel, W. A., Dinger, J. E., and Ruskin, R. E.: Vertical Profiles of CCN at Various Geographical Locations, J. Atmos. Sci., 30, 1410-1420, 1973.

Jaatinen, A., Romakkaniemi, S., Anttila, T., Hyvärinen, A.-P., Hao, L.-Q., Kortelainen, A., Miettinen, P., Mikkonen, S., Smith, J. N., Virtanen, A., and Laaksonen, A.: The third Pallas Cloud Experiment: Consistency between the aerosol hygroscopic growth and CCN activity (Suppl. B), Boreal Env. Res., 19, 368-382, 2014.

Komppula, M., Lihavainen, H., Hatakka, J., Paatero, J., Aalto, P., Kulmala, M., and Viisanen, Y.: Observations of new particle formation and size distributions at two different heights and surroundings in subarctic area in northern Finland, J. Geophys. Res., 108, 4295, doi:10.1029/2002JD002939, 2003.

Komppula, M., Lihavainen, H., Kerminen, V.-M., Kulmala, M., and Viisanen, Y.: Measurements of cloud droplet activation of aerosol particles at a clean subarctic background site, J. Geophys. Res., 110, D06204, doi:10.1029/2004JD005200, 2005.

Kreidenweis, S. M., Koehler, K., DeMott, P. J., Prenni, A. J., Carrico, C., and Ervens, B.: Water activity and activation diameters from hygroscopicity data - Part I: Theory and application to inorganic salts, Atmos. Chem. Phys., 5, 1357-1370, doi:10.5194/acp-5-1357-2005, 2005.

Kuang, C., McMurry, P. H., McCormick, A. V., and Eisele, F. L.: Dependence of nucleation rates on sulfuric acid vapor concentration in diverse atmospheric locations, J. Geophys. Res., 113, D10209, doi:10.1029/2007JD009253, 2008.

Kulmala, M., Kontkanen, J., Junninen, H., Lehtipalo, K., Manninen, H. E., Nieminen, T., Petäjä, T., Sipilä, M., Schobesberger, S., Rantala, P., Franchin, A., Jokinen, T., Järvinen, E., Äijälä, M., Kangasluoma, J., Hakala, J., Aalto, P. P., Paasonen, P., Mikkilä, J., Vanhanen, J., Aalto, J., Hakola, H., Makkonen, U., Ruuskanen, T., Mauldin III, R. L., Duplissy, J., Vehkamäki, H., Bäck, J., Kortelainen, A., Riipinen, I., Kurtén, T., Johnston, M. V., Smith,
J. N., Ehn, M., Mentel, T. F., Lehtinen, K. E. J., Laaksonen, A., Kerminen, V.-M., and Worsnop, D. R.: Direct Observations of Atmospheric Aerosol Nucleation, Science, 339, 943-946, 2013.

Lathem, T. L., Beyersdorf, A. J., Thornhill, K. L., Winstead, E. L., Cubison, M. J., Hecobian, A., Jimenez, J. L., Weber, R. J., Anderson, B. E., and Nenes, A.: Analysis of CCN activity of Arctic aerosol and Canadian biomass burning during summer 2008, Atmos. Chem. Phys., 13, 2735-2756, doi:10.5194/acp-13-27352013, 2013.

Martin, M., Chang, R. Y.-W., Sierau, B., Sjogren, S., Swietlicki, E., Abbatt, J. P. D., Leck, C., and Lohmann, U.: Cloud condensation nuclei closure study on summer arctic aerosol, Atmos. Chem. Phys., 11, 11335-11350, doi:10.5194/acp-11-11335-2011, 2011.

Moore, M. J. K., Furutani, H., Roberts, G. C., Moffet, R. C., Gilles, M. K., Palenik, B., and Prather, K. A.: Effect of organic compounds on cloud condensation nuclei $(\mathrm{CCN})$ activity of sea spray aerosol produced by bubble bursting, Atmos. Environ., 45, 74627469, 2011.

Moore, R. H., Bahreini, R., Brock, C. A., Froyd, K. D., Cozic, J., Holloway, J. S., Middlebrook, A. M., Murphy, D. M., and Nenes, A.: Hygroscopicity and composition of Alaskan Arctic CCN during April 2008, Atmos. Chem. Phys., 11, 11807-11825, doi:10.5194/acp-11-11807-2011, 2011.

Ortega, I. K., Suni, T., Boy, M., Grönholm, T., Manninen, H. E., Nieminen, T., Ehn, M., Junninen, H., Hakola, H., Hellén, H., Valmari, T., Arvela, H., Zegelin, S., Hughes, D., Kitchen, M., Cleugh, H., Worsnop, D. R., Kulmala, M., and Kerminen, V.-M.: New insights into nocturnal nucleation, Atmos. Chem. Phys., 12, 4297-4312, doi:10.5194/acp-12-4297-2012, 2012.

Paramonov, M., Aalto, P. P., Asmi, A., Prisle, N., Kerminen, V.M., Kulmala, M., and Petäjä, T.: The analysis of size-segregated cloud condensation nuclei counter (CCNC) data and its implications for cloud droplet activation, Atmos. Chem. Phys., 13, 10285-10301, doi:10.5194/acp-13-10285-2013, 2013.

Park, K., Kim, G., Kim, J.-S., Yoon, Y.-J., Cho, H.-J., and Ström, J.: Mixing State of Size-Selected Submicrometer Particles in the Arctic in May and September 2012, Environ. Sci. Technol., 48, 909-919, 2014.

Petters, M. D. and Kreidenweis, S. M.: A single parameter representation of hygroscopic growth and cloud condensation nucleus activity, Atmos. Chem. Phys., 7, 1961-1971, doi:10.5194/acp-71961-2007, 2007.

Pradeep Kumar, P., Broekhuizen, K., and Abbatt, J. P. D.: Organic acids as cloud condensation nuclei: Laboratory studies of highly soluble and insoluble species, Atmos. Chem. Phys., 3, 509-520, doi:10.5194/acp-3-509-2003, 2003.

Pruppacher, H. R. and Klett, J. D.: Microphysics of Clouds and Precipitation, Atmospheric and Oceanographic Sciences Library, Volume 18, ISBN 9780306481000, Springer, Dordrecht, the Netherlands, 2010.

Rastak, N., Silvergren, S., Zieger, P., Wideqvist, U., Ström, J., Svenningsson, B., Maturilli, M., Tesche, M., Ekman, A. M. L., Tunved, P., and Riipinen, I.: Seasonal variation of aerosol water uptake and its impact on the direct radiative effect at Ny-Ålesund, Svalbard, Atmos. Chem. Phys., 14, 7445-7460, doi:10.5194/acp14-7445-2014, 2014.

Riipinen, I., Sihto, S.-L., Kulmala, M., Arnold, F., Dal Maso, M., Birmili, W., Saarnio, K., Teinilä, K., Kerminen, V.-M., Laaksonen, A., and Lehtinen, K. E. J.: Connections between atmo- 
spheric sulphuric acid and new particle formation during QUEST III-IV campaigns in Heidelberg and Hyytiälä, Atmos. Chem. Phys., 7, 1899-1914, doi:10.5194/acp-7-1899-2007, 2007.

Rogers, R. R. and Yau, M. K.: A Short Course in Cloud Physics, 3rd edition, International Series in Natural Philosophy, 113, Butterworth-Heinemann an imprint of Elsvier, ISBN 0-75063215-1, reprint, 1996.

Rolph, G. D.: Real-time Environmental Applications and Display sYstem (READY) Website, NOAA Air Resources Laboratory, Silver Spring, MD, USA, available at: http://ready.arl.noaa.gov, last access: 7 August 2015.

Rose, D., Nowak, A., Achtert, P., Wiedensohler, A., Hu, M., Shao, M., Zhang, Y., Andreae, M. O., and Pöschl, U.: Cloud condensation nuclei in polluted air and biomass burning smoke near the mega-city Guangzhou, China - Part 1: Size-resolved measurements and implications for the modeling of aerosol particle hygroscopicity and CCN activity, Atmos. Chem. Phys., 10, 33653383, doi:10.5194/acp-10-3365-2010, 2010.

Shaw, G. E.: Cloud condensation nuclei associated with Arctic haze, Atmos. Environ., 20, 1453-1456, 1986.

Silvergren, S. Wideqvist, U., Ström, J., Sjogren, S., and Svenningsson, B.: Hygroscopic growth and cloud forming potential of Arctic aerosol based on observed chemical and physical characteristics (a 1 year study 2007-2008), J. Geophys. Res.-Atmos, 119, 14080-14097, 2014.

Sipilä, M., Berndt, T., Petäjä, T., Brus, D., Vanhanen, J., Stratmann, F., Patokoski, J., Mauldin III, R. L., Hyvärinen, A.-P., Lihavainen, H., and Kulmala, M.: The Role of Sulfuric Acid in Atmospheric Nucleation, Science, 327, 1243-1246, 2010.
Sullivan, R. C., Moore, M. J. K., Petters, M. D., Kreidenweis, S. M., Roberts, G. C., and Prather, K. A.: Effect of chemical mixing state on the hygroscopicity and cloud nucleation properties of calcium mineral dust particles, Atmos. Chem. Phys., 9, 33033316, doi:10.5194/acp-9-3303-2009, 2009.

Tunved, P., Ström, J., and Krejci, R.: Arctic aerosol life cycle: linking aerosol size distributions observed between 2000 and 2010 with air mass transport and precipitation at Zeppelin station, Ny-Ålesund, Svalbard, Atmos. Chem. Phys., 13, 3643-3660, doi:10.5194/acp-13-3643-2013, 2013

Yli-Juuti, T., Nieminen, T., Hirsikko, A., Aalto, P. P., Asmi, E., Hõrrak, U., Manninen, H. E., Patokoski, J., Dal Maso, M., Petäjä, T., Rinne, J., Kulmala, M., and Riipinen, I.: Growth rates of nucleation mode particles in Hyytiälä during 20032009: variation with particle size, season, data analysis method and ambient conditions, Atmos. Chem. Phys., 11, 12865-12886, doi:10.5194/acp-11-12865-2011, 2011.

Yum, S. S. and Hudson, J. G.: Vertical distributions of cloud condensation nuclei spectra over the springtime Arctic Ocean, J. Geophys. Res., 106, 15045-15052, 2001.

Zieger, P., Fierz-Schmidhauser, R., Gysel, M., Ström, J., Henne, S., Yttri, K. E., Baltensperger, U., and Weingartner, E.: Effects of relative humidity on aerosol light scattering in the Arctic, Atmos. Chem. Phys., 10, 3875-3890, doi:10.5194/acp-10-38752010, 2010. 